\title{
Buffalo milk increases viability and resistance of probiotic bacteria in dairy beverages under in vitro simulated gastrointestinal conditions
}

\author{
Thamires Maria Simões da Silva, ${ }^{1}$ Anna Carolina Meirelles Piazentin, ${ }^{1}$ Carlos Miguel Nóbrega Mendonça, ${ }^{1}$ \\ Attilio Converti, ${ }^{2}$ Cristina Stewart Bittencourt Bogsan, ${ }^{1}$ Diego Mora, ${ }^{3}$ \\ and Ricardo Pinheiro de Souza Oliveira ${ }^{1 *}$ \\ ${ }^{1}$ Department of Biochemical-Pharmaceutical Technology, Faculty of Pharmaceutical Sciences (FCF/USP), 05508-000 São Paulo, SP, Brazil \\ ${ }^{2}$ Department of Civil, Chemical and Environmental Engineering, Pole of Chemical Engineering, 16145 Genoa, Italy \\ ${ }^{3}$ Department of Food Environmental and Nutritional Sciences (DeFENS), University of Milan, 20133 Milan, Italy
}

\begin{abstract}
Probiotic dairy beverages prepared from buffalo and cow milks with different levels of whey $(0,25$, and $50 \%)$ were evaluated for kinetic fermentation parameters, protein and fat contents, post-acidification profile, viability of Streptococcus thermophilus, Lactobacillus bulgaricus, and Lactobacillus acidophilus during $21 \mathrm{~d}$ of refrigerated storage, and resistance to in vitro gastrointestinal conditions. Progressive acidification that occurred during storage of all dairy products was reduced in the presence of whey. Lactic acid bacteria showed viable cell counts at the end of shelf life, with the highest values (7.33 to $8.83 \log \mathrm{cfu} / \mathrm{mL}$ ) detected in buffalo dairy products. Compared with fermented cow milk products, those made with buffalo milk showed better bacterial viability during in vitro simulated gastrointestinal digestion, which suggests a beneficial protective effect on human microbiome.
\end{abstract}

Key words: buffalo milk, dairy beverage, probiotic, gastrointestinal stress, in vitro simulation

\section{INTRODUCTION}

Dairy beverages are products made by blending milk (in natura, pasteurized, sterilized, reconstituted, concentrated, powdered, whole, semi- or partially skimmed, or skim milk) with whey (liquid, concentrated, or powdered whey), vegetable fat, fermented milk or milks, selected milk ferments, and other dairy products (Ministério da Agricultura e do Abastecimento, Brazil, 2005). Whey is a by-product of the cheese industry with high nutritional value, which has serious environmental effects when improperly disposed of (Magalhães et al., 2011; Silva, 2015); therefore, its reuse is highly hoped for. With this aim in mind, when used to produce dairy

Received December 18, 2019.

Accepted April 13, 2020.

*Corresponding author: rpsolive@usp.br beverages, whey not only provides them with more fluidity but also reduces their cost.

Formulation of buffalo milk beverages may expand the range of products with different qualities than those traditionally made with cow milk. Compared with cow milk, buffalo milk has, in fact, nutritional characteristics that stand out, such as higher contents of fat, protein, lactose, and some minerals (calcium, iron, magnesium, and phosphorus), lower cholesterol level, and almost double the content of CLA (Ahmad et al., 2013; Guimarães et al., 2014). In addition, its higher contents of casein and fat are able to provide the final products with better gel consistency and more creaminess, respectively (Sfakianakis and Tzia, 2014).

The so-called probiotic dairy-based beverages contain probiotic bacteria, which are known to be "live microorganisms that, when administered in adequate amounts, confer a health benefit on the host" (FAO/WHO, 2002, p. 8). Consumption of probiotics contributes to the maintenance of health through benefits resulting from their direct action on the human gastrointestinal tract, stimulating the immune system and even enhancing the host's emotional health (de Vos and de Vos, 2012; Parker et al., 2018). To obtain potential health benefits, probiotics should be consumed regularly and must be present in sufficient viable quantities in products at the end of shelf life (about $10^{6}$ to $10^{8} \mathrm{cfu} / \mathrm{mL}$; Ertem and Çakmakçi, 2017). Probiotic viability in products can be influenced by several factors, such as the food matrix consistency, acidity of the food matrix, and the interaction between probiotic and starter culture (Mishra and Mishra, 2013; Casarotti and Penna, 2015). Therefore, product characterization, viability of probiotics in the product at the end of shelf life, and even their ability to survive in vitro simulated gastrointestinal stress conditions are essential to check compliance with their recommended intake (Casarotti and Penna, 2015).

Based on this background, the present study aims to compare the main attributes of probiotic dairy beverages prepared with buffalo milk and cow milk, using 
different proportions of whey during refrigerated storage. Dairy beverages were evaluated in terms of kinetic parameters, protein and fat contents, post-acidification profiles, and survival of probiotics through both shelf life and in vitro simulated gastrointestinal conditions.

\section{MATERIALS AND METHODS}

\section{Ingredients and Cultures}

Dairy beverages were formulated with buffalo milk and cheese whey supplied by the Fazenda Montenegro (Sorocaba, SP, Brazil), which breeds Murrah buffaloes. Commercial pasteurized cow milk (Fazenda Bela Vista, Tapiratiba, SP, Brazil) was also used to prepare dairy beverages. Cow milk was obtained from retail stores and the corresponding whey from the handicraft preparation of Minas Frescal type cheese. The following microorganisms were used to ferment milks: Streptococcus thermophilus TA040 (DuPont Danisco, Sassenage, France), Lactobacillus bulgaricus LB340 (DuPont Danisco), and Lactobacillus acidophilus La5 (Christian Hansen, Hørsholm, Denmark).

\section{Experimental Design}

Dairy products were prepared according to the central composite experimental design described in Table 1 , whereby they were divided depending on the milk type and the whey content used for their production. The design consisted of 6 different formulations of dairy products, 3 of which were prepared with buffalo milk (BM) and the other 3 with cow milk (CM). For the formulation of dairy drinks, cheese whey, at 0,25 , and $50 \%$ (vol/vol) proportions, was added after milk fermentation.

\section{Fermentation and Preparation of Dairy Products}

The milk base used, buffalo or cow milk, was heated at $90^{\circ} \mathrm{C}$ for 5 min using a Thermomix device (Vorwek and Co. KG, TM31, Wuppertal, Germany) and subsequently transferred to sterile Schott flasks, cooled in an ice bath, and stored under refrigeration at $4^{\circ} \mathrm{C}$ for 24 h. For fermentation, Schott flasks containing 500 $\mathrm{mL}$ of buffalo or cow milk were inoculated with Strep. thermophilus, L. bulgaricus, and L. acidophilus cultures up to an initial count of approximately $5.0 \mathrm{log} \mathrm{cfu} /$ $\mathrm{mL}$ each. Flasks were transferred to a water bath at $42^{\circ} \mathrm{C}$ and coupled with the Cinétique d'acidification system (Ysebaert, Frépillon, France), through which we could continuously monitor $\mathrm{pH}$ and acidification kinetic parameters such as the acidification rate $\left(\mathbf{V}_{\max }\right)$ expressed in $10^{-3} \mathrm{pH}$ units/min, the time and $\mathrm{pH}$ at
Table 1. Central composite experimental design used to prepare probiotic dairy beverages

\begin{tabular}{|c|c|c|c|}
\hline \multirow[b]{2}{*}{ Treatment $^{1}$} & \multirow[b]{2}{*}{ Milk } & \multicolumn{2}{|c|}{ Dairy base } \\
\hline & & $\begin{array}{c}\text { Whey } \\
(\%)\end{array}$ & $\begin{array}{c}\text { Milk } \\
(\%)\end{array}$ \\
\hline BM1 & Buffalo & 0 & 100 \\
\hline BM2 & & 25 & 75 \\
\hline BM3 & & 50 & 50 \\
\hline CM1 & Cow & 0 & 100 \\
\hline CM2 & & 25 & 75 \\
\hline CM3 & & 50 & 50 \\
\hline
\end{tabular}

${ }^{1} \mathrm{BM}=$ buffalo milk; $\mathrm{CM}=$ cow milk.

which $\mathrm{V}_{\max }$ was reached, and the times required to reach $\mathrm{pH}$ 5.5, 5.0, and 4.7. Fermentation was monitored via the CINAC system until pH 4.7 was reached, after which fermentation was stopped in an ice bath, and the matrix of the fermented product was broken using vertical movements of a steel rod with a perforated disk for about $60 \mathrm{~s}$. The fermented dairy bases were mixed with whey in the earlier defined proportions using the Thermomix device. Subsequently, the dairy products were placed in plastic pots with metal lids and stored at $4^{\circ} \mathrm{C}$ for $21 \mathrm{~d}$.

\section{Determination of Fat and Protein Contents}

To determine the fat content in dairy products, the Gerber method was used, which is based on the breakdown of milk emulsion. Briefly, $11 \mathrm{~mL}$ of the product was added slowly, with the aid of a volumetric pipette, to $10 \mathrm{~mL}$ of $95 \%$ sulfuric acid in a butyrometer. After addition of $1.0 \mathrm{~mL}$ of pure isoamyl alcohol, the butyrometer was capped with a cork stopper, carefully stirred until complete dissolution, centrifuged for 15 min at $161 \times g$, and heated in a bath at $65^{\circ} \mathrm{C}$ for $3 \mathrm{~min}$. The lipid portion of milk was expressed as percentage of fat present in the sample (Instituto Adolfo Lutz, 1985).

The protein content in dairy products was determined via the Kjeldahl method for total nitrogen. For this purpose, $2.0 \mathrm{~g}$ of potassium sulfate plus 12 to $14 \mathrm{~mL}$ of copper sulfate used as a catalyst were added to $1.0 \mathrm{~g}$ of sample previously placed in a digestion tube $(50 \times 250$ $\mathrm{mm})$. After further addition of $20 \mathrm{~mL}$ of sulfuric acid, the tubes were routed to the digester block (TE040, Tecnal, Piracicaba, SP, Brazil), where digestion was carried out at a temperature of 350 to $420^{\circ} \mathrm{C}$ until the samples achieved a translucent light green color (about $2 \mathrm{~h}$ ). After cooling, the tubes were placed in a distiller connected with 250-mL Erlenmeyer flasks containing $50 \mathrm{~mL}$ of boric acid, and phenolphthalein was added as an indicator. Distillation was performed after addition of $60 \mathrm{~mL}$ of $40 \% \mathrm{NaOH}$ and considered complete when 
the distillate volume reached $150 \mathrm{~mL}$. The distillate was then titrated with $0.1 \mathrm{~N} \mathrm{HCl}$, whose consumed volume allowed calculation of the percentage of nitrogen in the sample using a conversion factor of 6.38 , as indicated by the official method of the Instituto Adolfo Lutz (1985). All analyses were performed in duplicate $7 \mathrm{~d}$ after the fermentation and elaboration of dairy products.

\section{Post-Acidification Profile}

The post-acidification profile of dairy products was determined by measuring the $\mathrm{pH}$ after $1,7,14$, and $21 \mathrm{~d}$ of refrigerated storage $\left(4^{\circ} \mathrm{C}\right)$ using a digital $\mathrm{pH}$ meter (Mettler-Toledo, Schwerzenbach, Switzerland) duly calibrated with buffer solutions (Merck-Millipore, Darmstadt, Germany) at pH 7.0 and 4.0 (Instituto Adolfo Lutz, 1985).

\section{Counts of Viable Bacteria}

Streptococcus thermophilus and L. bulgaricus were counted on M17 and de Man, Rogosa, and Sharpe agar (MRS; Difco, Le Pont de Claix, France), respectively, at $\mathrm{pH} 5.4$ and incubated at $37^{\circ} \mathrm{C}$ for $72 \mathrm{~h}$. The cultivation media were prepared according to Saccaro et al. (2011). Lactobacillus acidophilus was enumerated using modified MRS agar medium supplemented with 50\% maltose solution after incubation at $37^{\circ} \mathrm{C}$ for $72 \mathrm{~h}$ in an anaerobic jar (Dave and Shah, 1997). Anaerobic conditions were established using GasPack (BD GasPack EZ, Dublin, Ireland). Plates containing from 30 to 300 colonies were chosen for enumeration, which was expressed in colony forming units per milliliter of product (cfu/ $\mathrm{mL}$ ). Analyses were performed in triplicate over $21 \mathrm{~d}$ of refrigerated storage.

\section{In Vitro Gastrointestinal Stress in Static Mode}

The in vitro gastrointestinal stress resistance of microorganisms was checked in the dairy beverages on the seventh day of refrigerated storage through a static digestion model adapted from Bedani et al. (2013). This model is divided into 3 phases: (i) the gastric phase (stomach), (ii) the first enteric phase (small intestine), and (iii) the second enteric phase (large intestine). At the end of each phase, aliquots of the samples were taken for viable bacteria counting.

For the analysis, $10 \mathrm{~mL}$ of a solution made with 25 $\mathrm{mL}$ of milk beverage samples and $225 \mathrm{~mL}$ of saline $(\mathrm{NaCl} 0.85 \%)$ was transferred to $500-\mathrm{mL}$ bottles. In the gastric phase (i), the $\mathrm{pH}$ of samples was adjusted to a range of 2.4 to 2.7 using $1.0 \mathrm{~N} \mathrm{HCl}$. Pepsin (Henrifarma Chemicals and Pharmaceuticals, São Paulo, SP,
Brazil) and lipase (Amano lipase G, from Penicillium camemberti, Sigma-Aldrich, St. Louis, MO) solutions were then added at concentrations of 3.0 and $0.9 \mathrm{mg} / \mathrm{L}$, respectively. The flasks were then incubated in a metabolic bath (Maxi-Shake, Heto-Holten, Allerød, Denmark) at $37^{\circ} \mathrm{C}$ under agitation of $150 \mathrm{rpm}$ for $2 \mathrm{~h}$. In the first enteric phase (ii) the $\mathrm{pH}$ was increased to 6.0 to 6.3 using a $1.0 \mathrm{~N} \mathrm{NaOH}$ solution in phosphate buffer. Subsequently, solutions of $10 \mathrm{~g} / \mathrm{L}$ of bile (porcine bile extract, Sigma-Aldrich) and $1.0 \mathrm{~g} / \mathrm{L}$ pancreatin (Pancreatin 3 NF, Henrifarma Chemicals and Pharmaceuticals, Cambuci, SP, Brazil) were added before the flasks were again incubated in a bath at $37^{\circ} \mathrm{C}$ and 150 $\mathrm{rpm}$ for $2 \mathrm{~h}$. In the second enteric phase (iii) the $\mathrm{pH}$ of the same bile and pancreatin solutions used for the first enteric phase was adjusted to 7.2 to 7.4 with the previously described $1.0 \mathrm{~N} \mathrm{NaOH}$ solution in phosphate buffer. Finally, the flasks were again incubated at $37^{\circ} \mathrm{C}$ and $150 \mathrm{rpm}$ for $2 \mathrm{~h}$.

\section{Statistical Analysis}

Data were treated by multivariate ANOVA and mean comparison tests using the Minitab 17.0 program (Minitab Inc., State College, PA) to determine the statistical significance of differences among means. Mean values were compared using the Tukey's test at $P \leq$ 0.05 .

\section{RESULTS AND DISCUSSIONS}

\section{Fermentation Kinetics}

Both buffalo and cow milks were fermented by a mixture of the Strep. thermophilus and L. bulgaricus starter culture and the probiotic bacterium $L$. acidophilus. The kinetic parameters of these fermentations are listed in Table 2.

The maximum rate of acidification $\left(\mathrm{V}_{\max }\right)$ in cow milk $\left(17.45 \times 10^{-3} \mathrm{upH} / \mathrm{min}\right)$ was $8.2 \%$ higher than in buffalo milk, which led to significant differences in all kinetic parameters and, in particular, to 17.1, 7.5, and $5.3 \%$ reductions in the values of the times to reach $\mathrm{pH}$ $4.7, \mathrm{~V}_{\max }$, and $\mathrm{pH} 5.0$, respectively (Table 2). This result may be associated with relevant differences in cow and buffalo milk compositions. Particularly, the $22 \%$ higher total solid content in buffalo milk $(16.54 \mathrm{~g} / 100$ g) compared with cow milk agrees with the observations of other authors (Ahmad et al., 2013; Khedkar et al., 2016). According to Kristo et al. (2003), the lower the total solid content, the poorer the buffering capacity, which in turn leads to a higher $\mathrm{pH}$ decrease for a given amount of acid produced. 
Table 2. Kinetic parameters of fermentation of buffalo and cow milks by Streptococcus thermophilus, Lactobacillus bulgaricus, and Lactobacillus acidophilus ${ }^{1}$

\begin{tabular}{|c|c|c|c|c|c|c|c|}
\hline Milk & Initial pH & $\begin{array}{l}\mathrm{t}_{\mathrm{pH} 5.5} \\
(\mathrm{~h})\end{array}$ & $\begin{array}{l}\mathrm{t}_{\mathrm{pH} 5.0} \\
(\mathrm{~h})\end{array}$ & $\begin{array}{l}\mathrm{t}_{\mathrm{pH} 4.7} \\
(\mathrm{~h})\end{array}$ & $\begin{array}{c}\mathrm{V}_{\max } \\
\left(10^{-3} \mathrm{upH} \cdot \mathrm{min}^{-1}\right)\end{array}$ & $\begin{array}{l}\mathrm{t}_{\max } \\
(\mathrm{h})\end{array}$ & $\mathrm{pH}_{\max }$ \\
\hline Buffalo & $6.65 \pm 0.05^{\mathrm{a}}$ & $2.87 \pm 0.12^{\mathrm{a}}$ & $3.80 \pm 0.04^{\mathrm{b}}$ & $4.67 \pm 0.04^{\mathrm{b}}$ & $16.13 \pm 0.15^{\mathrm{a}}$ & $2.70 \pm 0.04^{\mathrm{b}}$ & $5.57 \pm 0.06^{\mathrm{a}}$ \\
\hline Cow & $6.57 \pm 0.03^{\mathrm{a}}$ & $2.73 \pm 0.12^{\mathrm{a}}$ & $3.60 \pm 0.02^{\mathrm{a}}$ & $3.87 \pm 0.06^{\mathrm{a}}$ & $17.45 \pm 0.31^{\mathrm{b}}$ & $2.50 \pm 0.03^{\mathrm{a}}$ & $5.41 \pm 0.08^{\mathrm{a}}$ \\
\hline
\end{tabular}

${ }^{a, b}$ Different superscript letters in the same column indicate statistically significant difference $(P \leq 0.05)$.

${ }^{1}$ Values are expressed as means $\pm \mathrm{SE}(\mathrm{n}=3) . \mathrm{t}_{\mathrm{pH} 5.5}=$ time required to reach $\mathrm{pH} 5.5 ; \mathrm{t}_{\mathrm{pH} 5.0}=$ time required to reach $\mathrm{pH} 5.0 ; \mathrm{t}_{\mathrm{pH} 4.7}=$ time required to reach $\mathrm{pH} 4.7 ; \mathrm{V}_{\max }=$ acidification rate, $10^{-3} \mathrm{pH}$ units $/ \mathrm{min} ; \mathrm{t}_{\max }=$ time at which $\mathrm{V}_{\max }$ was reached; $\mathrm{pH}_{\max }=\mathrm{pH}$ at which $\mathrm{V}_{\max } \mathrm{was}$ reached.

Almeida et al. (2009), who investigated the influence of total solid content on whey fermentation by Strep. thermophilus in coculture with $L$. bulgaricus, observed a $34 \%$ increase in the maximum acidification rate and an $18 \%$ decrease in the time needed to complete fermentation when the total solids content of whey was increased from 8 to $12 \mathrm{~g} / 100 \mathrm{~g}$. Similar values of acidification kinetic parameters were found by other authors for cow milk fermentation by different probiotic bacteria (Florence et al., 2012; Oliveira et al., 2012; Casarotti and Penna, 2015).

\section{Fat and Protein Contents}

The results of fat and protein contents of dairy products and milks are listed in Table 3. The fat contents of milks used to prepare dairy products were significantly different $(P \leq 0.05)$, with that of buffalo milk (5.15 $\mathrm{g} / 100 \mathrm{~g}$ ) about $58 \%$ higher than that of cow milk. As expected, fat content in dairy products decreased when whey was added to their formulation. In particular, fermented buffalo (FBM) and cow milks (FCM) without added whey (FBM1 and FCM1) showed no significant difference $(P \geq 0.05)$ compared with their respective controls (BM and CM). However, compared with controls, the fermented dairy beverages with $25 \%$ whey in their compositions (FBM2 and FCM2) showed reductions of about 28 and $21 \%$ in the fat content, whereas those with $50 \%$ whey showed reductions as large as $44 \%$ (FBM3) and 47\% (FCM3). Higher fat content $(9.60 \mathrm{~g} / 100 \mathrm{~g})$ was reported by Blasi et al. (2008) for milk of Italian buffalo.

The addition of whey also reduced the protein content in dairy products. The fermented cow milk enriched with $50 \%$ whey (FCM3) exhibited the lowest protein content $(2.09 \mathrm{~g} / 100 \mathrm{~g})$, representing a $27 \%$ reduction compared with the same fermented milk without any whey addition (FCM1), whereas FBM3, FCM1, and FCM2 did not show any significant differences among them $(P \geq 0.05)$. By contrast, the protein content of the control buffalo milk $(3.53 \mathrm{~g} / 100 \mathrm{~g})$ was about $10 \%$ higher than that of cow milk $(P \leq 0.05)$, likely due to its higher thermoresistance (Akgun et al., 2016).
Higher protein contents were reported for buffalo milks from different breeds and countries (4.54 to 4.92 g/100 g; Yadav et al., 2007; Zhou et al., 2018), whereas those of cow and buffalo milk yogurts (Guimarães et al., $2014 ; 2.61$ to $2.71 \mathrm{~g} / 100 \mathrm{~g}$ ) were close to the values obtained in the present study for the fermented products without any whey addition (FBM1 and FCM1). It has been proposed that regional variations may greatly influence the chemical composition of buffalo milk, especially in terms of fat and protein contents (Akgun et al., 2016).

\section{Post-Acidification Profile}

As expected, $\mathrm{pH}$ decreased similarly throughout storage in all dairy products due to progressive lactic acid formation $(P \leq 0.05)$, even though the extent of postacidification of buffalo milk products was lower than that of cow milk products (Table 4). In fact, whereas the $\mathrm{pH}$ of fermented buffalo milk products ranged from 4.37 to 4.48 during refrigerated storage, consistent with observations by Akgun et al. (2016) (4.35 to 4.38), that of fermented cow milk products was 4.32 on average.

Table 3. Fat and protein contents of dairy products and milks ${ }^{1}$

\begin{tabular}{lcc}
\hline $\begin{array}{l}\text { Dairy product } \\
\text { or milk }\end{array}$ & Fat $(\mathrm{g} / 100 \mathrm{~g})$ & Protein $(\mathrm{g} / 100 \mathrm{~g})$ \\
\hline FBM1 & $5.10 \pm 0.08^{\mathrm{a}}$ & $4.28 \pm 0.03^{\mathrm{a}}$ \\
FBM2 & $3.68 \pm 0.12^{\mathrm{b}}$ & $3.89 \pm 0.03^{\mathrm{b}}$ \\
FBM3 & $2.87 \pm 0.01^{\mathrm{cd}}$ & $2.71 \pm 0.01^{\mathrm{e}}$ \\
FCM1 & $3.52 \pm 0.14^{\mathrm{b}}$ & $2.88 \pm 0.03^{\mathrm{e}}$ \\
FCM2 & $2.56 \pm 0.13^{\mathrm{d}}$ & $2.71 \pm 0.01^{\mathrm{e}}$ \\
FCM3 & $1.70 \pm 0.17^{\mathrm{e}}$ & $2.09 \pm 0.03^{\mathrm{f}}$ \\
BM & $5.15 \pm 0.07^{\mathrm{a}}$ & $3.53 \pm 0.07^{\mathrm{c}}$ \\
CM & $3.25 \pm 0.21^{\mathrm{bc}}$ & $3.21 \pm 0.11^{\mathrm{d}}$ \\
\hline
\end{tabular}

$\overline{\mathrm{a} f}$ Different letters in the same column indicate statistically significant difference $(P \leq 0.05)$.

${ }^{1}$ Values are expressed as means $\pm \mathrm{SE}(\mathrm{n}=3)$.

${ }^{2} \mathrm{FBM}=$ fermented buffalo milk product. $\mathrm{FBM} 1=\mathrm{FBM}$ containing $0 \%$ whey, $100 \%$ milk; FBM $2=25 \%$ whey, $75 \%$ milk; FBM3 $=50 \%$ whey, $50 \%$ milk. FCM $=$ fermented cow milk product. FCM1 $=$ FCM containing $0 \%$ whey, $100 \%$ milk; FCM $2=25 \%$ whey, $75 \%$ milk; FCM 3 $=50 \%$ whey, $50 \%$ milk. 
a)

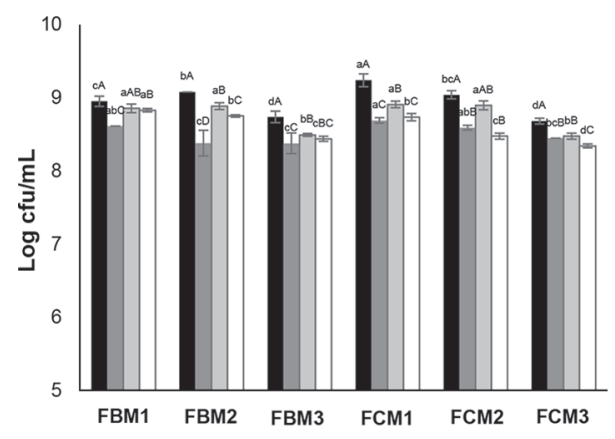

b)

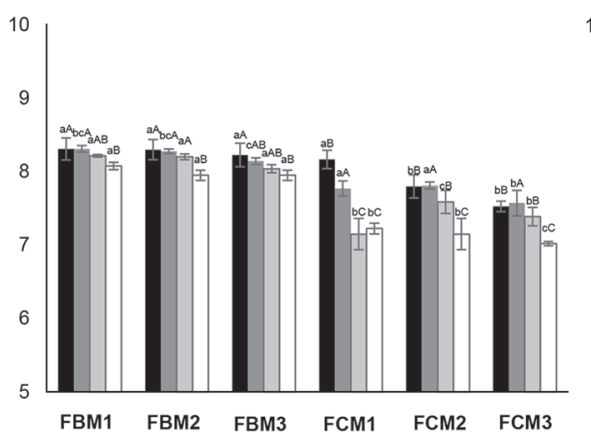

c)

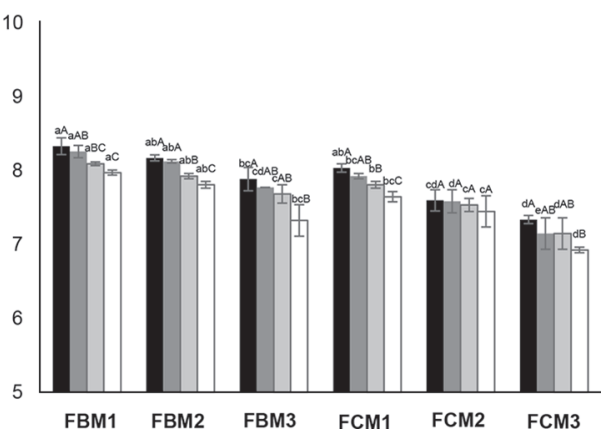

Figure 1. Viable counts of Streptococcus thermophilus (a), Lactobacillus bulgaricus (b), and Lactobacillus acidophilus (c) in dairy products after 1 (black bars), 7 (dark gray bars), 14 (light gray bars), and 21 (white bars) d of refrigerated storage. Different lowercase letters indicate significant differences $(P \leq 0.05)$ among dairy products on the same day. Different capital letters indicate significant differences $(P \leq 0.05)$ for the same product throughout the storage period. Fermented buffalo milk product containing $0 \%$ whey, $100 \%$ milk (FBM1); $25 \%$ whey, $75 \%$ milk (FBM2); and 50\% whey, 50\% milk (FBM3). Fermented cow milk product containing 0\% whey, 100\% milk (FCM1); 25\% whey, $75 \%$ milk (FCM2); and $50 \%$ whey, $50 \%$ milk (FCM3).

\section{Counts of Viable Bacteria}

Several factors are reported to influence viability of bacteria in dairy products, among them $\mathrm{pH}$, milk matrix composition, product formulation, microbial interactions, presence of food additives, hydrogen peroxide and dissolved oxygen levels, concentration of acidic metabolites, and product buffering capacity throughout shelf life (Karimi et al., 2011; Mousavi et al., 2019; Tavakoli et al., 2019).

Although Strep. thermophilus enumerations were significantly different $(P \leq 0.05)$ between fermented buffalo and cow milks, all they remained quite high throughout the 21-d refrigerated storage, being as high as $8.83 \pm 0.02 \log \mathrm{cfu} / \mathrm{mL}$ in FBM1 and $8.34 \pm 0.03 \mathrm{log}$ $\mathrm{cfu} / \mathrm{mL}$ in FCM3 at the end of shelf life (Figure 1a). Such a stability of Strep. thermophilus counts in dairy products was also observed by Casarotti and Penna (2015) and Mousavi et al. (2019).

In contrast, L. bulgaricus showed better viability in fermented beverages made with buffalo rather than cow milk. In particular, FBM1 showed the least decrease of L. bulgaricus enumeration, $8.31 \pm 0.15 \log \mathrm{cfu} / \mathrm{mL}$ after $1 \mathrm{~d}$ and $8.08 \pm 0.05 \log \mathrm{cfu} / \mathrm{mL}$ after $21 \mathrm{~d}$ of storage (Figure 1b). Compared with dairy products made with buffalo milk, those made with cow milk suffered a more significant loss in L. bulgaricus viability throughout storage, especially in the case of the wheyless product (FCM1; $1.02 \log \mathrm{cfu} / \mathrm{mL}$ ).

A gradual decrease also occurred in L. acidophilus counts throughout storage (Figure 1c), with the lowest value $(6.93 \pm 0.04 \log \mathrm{cfu} / \mathrm{mL})$ detected in FCM3. It is likely that the higher fat content in fermented buffalo milk preserved the viability of $L$. bulgaricus and $L$.

Table 4. $\mathrm{pH}$ values of dairy products during shelf life at $4^{\circ} \mathrm{C}$ for $1,7,14$, and $21 \mathrm{~d}^{1}$

\begin{tabular}{|c|c|c|c|c|}
\hline \multirow{2}{*}{$\begin{array}{l}\text { Dairy } \\
\text { product }^{2}\end{array}$} & \multicolumn{4}{|c|}{ Shelf life (d) } \\
\hline & 1 & 7 & 14 & 21 \\
\hline FBM1 & $4.58 \pm 0.04^{\mathrm{b}, \mathrm{A}}$ & $4.46 \pm 0.03^{\mathrm{c}, \mathrm{B}}$ & $4.41 \pm 0.05^{\mathrm{b}, \mathrm{B}}$ & $4.37 \pm 0.04^{\mathrm{b}, \mathrm{B}}$ \\
\hline FBM2 & $4.57 \pm 0.04^{\mathrm{b}, \mathrm{A}}$ & $4.49 \pm 0.02^{\mathrm{d}, \mathrm{B}}$ & $4.45 \pm 0.03^{\mathrm{b}, \mathrm{B}}$ & $4.39 \pm 0.02^{\mathrm{b}, \mathrm{C}}$ \\
\hline FBM3 & $4.67 \pm 0.03^{\mathrm{a}, \mathrm{A}}$ & $4.58 \pm 0.01^{\mathrm{a}, \mathrm{B}}$ & $4.50 \pm 0.03^{\mathrm{a}, \mathrm{C}}$ & $4.48 \pm 0.02^{\mathrm{a}, \mathrm{C}}$ \\
\hline FCM1 & $4.45 \pm 0.02^{\mathrm{c}, \mathrm{A}}$ & $4.41 \pm 0.02^{\mathrm{c}, \mathrm{B}}$ & $4.33 \pm 0.01^{\mathrm{d}, \mathrm{C}}$ & $4.26 \pm 0.01^{\mathrm{d}, \mathrm{D}}$ \\
\hline FCM2 & $4.46 \pm 0.02^{\mathrm{c}, \mathrm{A}}$ & $4.41 \pm 0.02^{\mathrm{c}, \mathrm{B}}$ & $4.37 \pm 0.01^{\mathrm{d}, \mathrm{C}}$ & $4.33 \pm 0.03^{\mathrm{c}, \mathrm{D}}$ \\
\hline FCM3 & $4.50 \pm 0.05^{\mathrm{b}, \mathrm{A}}$ & $4.53 \pm 0.01^{\mathrm{b}, \mathrm{A}}$ & $4.41 \pm 0.03^{\mathrm{b}, \mathrm{B}}$ & $4.39 \pm 0.01^{\mathrm{b}, \mathrm{B}}$ \\
\hline
\end{tabular}

${ }^{\mathrm{a}-\mathrm{d}}$ Different lowercase letters in the same column indicate significant differences $(P \leq 0.05)$ among different dairy products after the same length of shelf life.

${ }^{\mathrm{A}-\mathrm{D}}$ Different capital letters in the same row indicate significant differences $(P \leq 0.05)$ for the same product after different lengths of shelf life.

${ }^{1}$ Values are expressed as means of 3 determinations $(n=3) \pm$ SD.

${ }^{2} \mathrm{FBM}=$ fermented buffalo milk product. FBM1 = FBM containing $0 \%$ whey, $100 \%$ milk; FBM $2=25 \%$ whey, $75 \%$ milk; FBM3 $=50 \%$ whey, $50 \%$ milk. FCM $=$ fermented cow milk product. FCM1 $=$ FCM containing $0 \%$ whey, $100 \%$ milk; FCM2 $=25 \%$ whey, $75 \%$ milk; FCM3 $=50 \%$ whey, $50 \%$ milk. 
acidophilus by increasing their acidity resistance during shelf life (Verruck et al., 2015). However, Akgun et al. (2016) reported that L. bulgaricus population was not significantly affected in buffalo milk yogurts during a 20-d storage period.

Bearing in mind that counts of probiotic bacteria in dairy products should range between $10^{6}$ and $10^{8}$ $\mathrm{cfu} / \mathrm{mL}$ during shelf life to provide health benefits to the host, and that these microorganisms must survive through the digestive tract (Granato et al., 2010; Ertem and Çakmakçi, 2017), the results obtained in the present work are in agreement with what is recommended for a probiotic product.

\section{Survival of In Vitro Gastrointestinal Stress}

The simulation of gastrointestinal stress under the typical conditions of the human digestive system, such as $\mathrm{pH}$ and bile salts, allows evaluation of the influence of these conditions on bacterial viability (Uriot et al., 2017). Figure 2 illustrates the viability of lactic bacteria used in this study to produce dairy products throughout each phase of the in vitro gastrointestinal test.

In general, bacteria suffered a progressive reduction of their viability in dairy products, due to the strongly acidic conditions simulating the digestive tract (Verruck et al., 2015). The viability of microorganisms, whose counts before the simulation varied from 8 to $9 \log \mathrm{cfu} / \mathrm{mL}$, did in fact decrease significantly $(P \leq$ $0.05)$ in all fermented products as soon as after the gastric phase. Particularly, viable counts of Strep. thermophilus, L. bulgaricus, and L. acidophilus were more affected in dairy drinks made with cow milk, especially those containing 50\% whey (FCM3), which suffered reductions as high as $3.66,4.11$, and $3.12 \log \mathrm{cfu} / \mathrm{mL}$, respectively.

In the first enteric phase, L. bulgaricus had its viability completely suppressed, no viable cells being detectable in FCM3, whereas Strep. thermophilus and $L$. acidophilus exhibited generalized decrease in viability, especially in FCM3, where counts fell to $2.22 \pm 0.13$ and $1.93 \pm 0.02 \log \mathrm{cfu} / \mathrm{mL}$, respectively. As proposed by Bedani et al. (2013), the action of bile in this simulation phase may have affected bacterial phospholipids and membrane proteins, making cell homeostasis difficult. Ziar et al. (2014) also observed high sensitivity of L. bulgaricus and Strep. thermophilus to bile action.

In the second enteric phase, no viable cells of any of the microorganisms under investigation were detected in FCM3, whereas only L. acidophilus showed viability in FCM2 $(2.42 \pm 0.13 \log \mathrm{cfu} / \mathrm{mL})$. Indeed, L. acidophilus remained viable in all dairy products, its counts being especially high in FBM1 (4.85 $\pm 0.05 \log \mathrm{cfu} /$ $\mathrm{mL})$ and FBM2 $(4.19 \pm 0.06 \log \mathrm{cfu} / \mathrm{mL})$. These results confirm the high survival capacity already shown by L. acidophilus in strongly acidic environments as well as in fermented milks with different fruit flours after in vitro gastrointestinal stress (Casarotti and Penna, 2015). In this same phase, Strep. thermophilus viability remained high in both FBM1 (4.65 $\pm 0.21 \log \mathrm{cfu} /$ $\mathrm{mL})$ and FCM1 $(2.41 \pm 0.11 \mathrm{log} \mathrm{cfu} / \mathrm{mL})$. Although it has long been believed that this bacterium would be unable to survive the digestive tract, several studies have reported its resistance to drastic gastrointestinal conditions (Boke et al., 2010; Fang et al., 2013; Ziar et a)

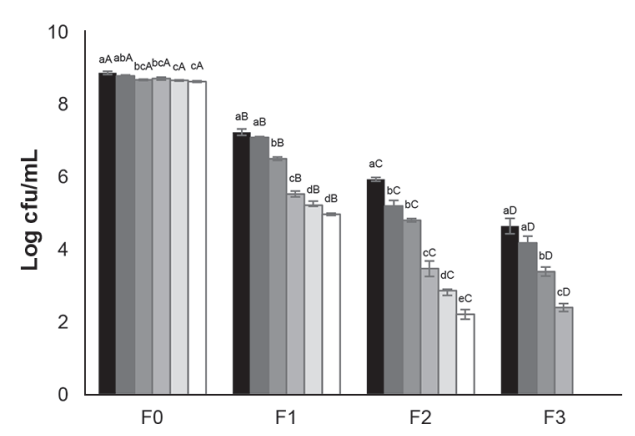

b)

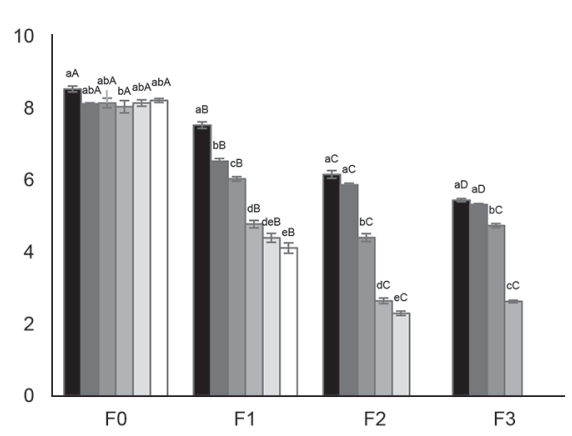

c)

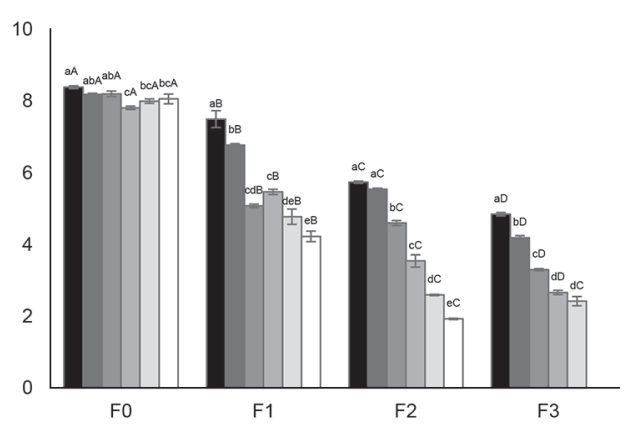

Figure 2. Survival of Streptococcus thermophilus (a), Lactobacillus bulgaricus (b), and Lactobacillus acidophilus (c) during in vitro simu-

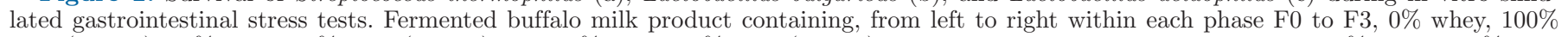

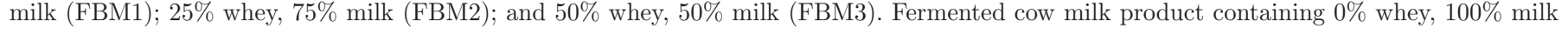

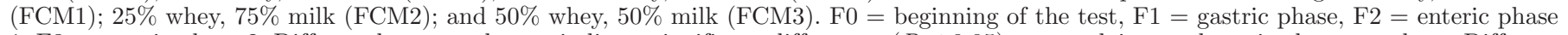

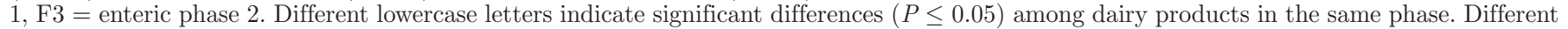
capital letters indicate significant differences $(P \leq 0.05)$ for the same product in different phases. 
al., 2014; Junjua et al., 2016). This capacity seems to depend not only on the ability of the strain to produce extracellular polysaccharides but also on the type of carbon source available in the medium (Boke et al., 2010; Uriot et al., 2017). Ziar et al. (2014) did in fact observe greater resistance of Strep. thermophilus to the action of bile in media containing lactose as the only carbon source.

Although the bacteria used in this study had their populations significantly diminished throughout the gastrointestinal simulation test, they remained more viable in dairy products made with buffalo rather than cow milk. The higher fat content in buffalo milk may have exerted a protective effect on cultures from the gastrointestinal stress by increasing their resistance to both acidic conditions and bile action (Verruck et al., 2015). Likewise, Ranadheera et al. (2012) observed higher survival of L. acidophilus in ice cream and goat milk yogurt containing $10 \%$ fat submitted to in vitro gastrointestinal stress.

\section{CONCLUSIONS}

Streptococcus thermophilus, L. bulgaricus, and L. acidophilus were used to produce fermented products from buffalo and cow milks. Dairy products made with buffalo milk showed lower post-acidification during shelf life than those made with cow milk. In addition, the viability of lactic acid bacteria used to prepare the fermented products was better preserved in fermented buffalo milk for up to $21 \mathrm{~d}$ of refrigerated storage. In particular, the viability of L. acidophilus was so high as to guarantee the number of viable cells recommended for probiotic products. Likewise, during in vitro simulation of gastrointestinal stress, the bacteria used to produce milk beverages displayed better survival in buffalo milk, which could then be used as a promising alternative milk matrix for the delivery of probiotics. Future studies will be performed with whey derived from buffalo milk products, to evaluate the differences with those derived from local cheese production using cow milk.

\section{ACKNOWLEDGMENTS}

The authors acknowledge the financial support of the National Council for Scientific and Technological Development (CNPq, Brasilia, Brazil), Coordenação de Aperfeiçoamento de Pessoal de Nível Superior (CAPES, Brasilia, Brazil) finance code 001, and the São Paulo Research Foundation (FAPESP, São Paulo, Brazil; processes no. 2018/25511-1 and 2019/19054-0). The authors have not stated any conflicts of interest.

\section{REFERENCES}

Ahmad, S., F. M. Anjum, N. Huma, A. Sameen, and T. Zahoor. 2013. Composition and physico-chemical characteristics of buffalo milk with particular emphasis on lipids, proteins, mineral, enzymes and vitamins. J. Anim. Plant Sci. 23:62-74.

Akgun, A., F. Yazici, and H. A. Gulec. 2016. Effect of reduced fat content on the physicochemical and microbiological properties of buffalo milk yoghurt. Lebensm. Wiss. Technol. 74:521-527. https: //doi.org/10.1016/j.lwt.2016.08.015.

Almeida, K. E., A. Y. Tamime, and M. N. Oliveira. 2009. Influence of total solids contents of milk whey on the acidifying profile and viability of various lactic acid bacteria. Lebensm. Wiss. Technol. 42:672-678. https://doi.org/10.1016/j.lwt.2008.03.013.

Bedani, R., E. A. Rossi, and S. M. Isay Saad. 2013. Impact of inulin and okara on Lactobacillus acidophilus LA-5 and Bifidobacterium animalis Bb-12 viability in fermented soy product and probiotic survival under in vitro simulated gastrointestinal conditions. Food Microbiol. 34:382-389. https://doi.org/10.1016/j.fm.2013.01.012.

Blasi, F., D. Montesano, M. De Angelis, A. Maurizi, F. Ventura, L. Cossignani, M. S. Simonetti, and P. Damiani. 2008. Results of stereospecific analysis of triacylglycerol fraction from donkey, cow, ewe, goat and buffalo milk. J. Food Compos. Anal. 21:1-7. https:/ /doi.org/10.1016/j.jfca.2007.06.005.

Boke, H., B. Aslim, and G. Alp. 2010. The role of resistance to bile salts and acid tolerance of exopolysaccharides (EPSS) produced by yogurt starter bacteria. Arch. Biol. Sci. Bel. 62:323-328. https:// doi.org/10.2298/ABS1002323B.

Casarotti, S. N., and A. L. B. Penna. 2015. Acidification profile, probiotic in vitro gastrointestinal tolerance and viability in fermented milk with fruit flours. Int. Dairy J. 41:1-6. https://doi.org/10 .1016/j.idairyj.2014.08.021.

Dave, R. I., and N. P. Shah. 1997. Viability of yoghurt and probiotic bacteria in yoghurts made from commercial starter cultures. Int. Dairy J. 7:31-41. https://doi.org/10.1016/S0958-6946(96)00046-5.

de Vos, W. M., and E. A. J. de Vos. 2012. Role of the intestinal microbiome in health and disease: From correlation to causation. Nutr. Rev. 70:S45-S56. https://doi.org/10.1111/j.1753-4887.2012 $.00505 . \mathrm{x}$.

Ertem, H., and S. Çakmakçi. 2017. Shelf life and quality of probiotic yogurt produced with Lactobacillus acidophilus and Gobdin. Int. J. Food Sci. Technol. 53:776-783. https://doi.org/10.1111/ijfs.13653.

Fang, S. H., Y. J. Lai, and C. C. Chou. 2013. The susceptibility of Streptococcus thermophilus 14085 to organic acid, simulated gastric juice, bile salt and disinfectant as influenced by cold shock treatment. Food Microbiol. 33:55-60. https://doi.org/10.1016/j.fm .2012.08.012.

FAO/WHO. 2002. Guidelines for the evaluation of probiotics in food: Report of a joint FAO/WHO working group on drafting guidelines for the evaluation of probiotics in food. FAO/WHO, London, ON, Canada.

Florence, A. C. R., R. P. S. Oliveira, R. C. Silva, F. A. S. M. Soares, L. A. Gioielli, and M. N. Oliveira. 2012. Organic milk improves Bifidobacterium lactis counts and bioactive fatty acids contents in fermented milk. Lebensm. Wiss. Technol. 49:89-95. https://doi .org/10.1016/j.lwt.2012.04.023.

Granato, D., G. F. Branco, A. G. Cruz, J. A. F. Faria, and N. P. Shah. 2010. Probiotic dairy products as functional foods. Compr. Rev. Food Sci. Food Saf. 9:455-470. https://doi.org/10.1111/j.1541 $-4337.2010 .00120 . x$

Guimarães, D. H. P., F. R. S. R. Silva, and N. M. Lênthola. 2014. Dairy products production with buffalo milk. Int. J. Appl. Sci. Technol. 4:3.

Instituto Adolfo Lutz. 1985. Normas analíticas do Instituto Adolfo Lutz: Métodos químicos e físicos para análise de alimentos [Analytical standards of the Adolfo Lutz Institute: Chemical and physical methods for food analysis]. 3rd. ed. Imprensa Oficial do Estado de São Paulo [Official Press of the State of São Paulo], São Paulo, Brazil.

Junjua, M., N. Kechaou, F. Chain, A. A. Awussi, Y. Roussel, C. Perrin, E. Roux, P. Langella, L. G. Bermúdez-Humarán, Y. Le Roux, 
J. Chatel, and A. Dary-Mourot. 2016. A large scale in vitro screening of Streptococcus thermophilus strains revealed strains with a high anti-inflammatory potential. LWT Food Sci. Technol. 70:7887. https://doi.org/10.1016/j.lwt.2016.02.006.

Karimi, R., A. M. Mortazavian, and A. G. Da Cruz. 2011. Viability of probiotic microorganisms in cheese during production and storage: A review. Dairy Sci. Technol. 91:283-308. https://doi.org/10 .1007/s13594-011-0005-x.

Khedkar, C. D., S. D. Kalyankar, and S. S. Deosarkar. 2016. Buffalo milk. Pages 522-528 in Encyclopedia of Food and Health. B. Caballero, P. M. Finglas, and F. Toldrá, ed. Elsevier Ltd., Amsterdam, the Netherlands.

Kristo, E., C. G. Biliaderis, and N. Tzanetakis. 2003. Modelling of rheological, microbiological and acidification properties of a fermented milk product containing a probiotic strain of Lactobacillus paracasei. Int. Dairy J. 13:517-528. https://doi.org/10.1016/S0958 -6946(03)00074-8.

Magalhães, K. T., G. Dragone, G. V. de Melo Pereira, J. M. Oliveira, L. Domingues, J. A. Teixeira, J. B. A. e Silva, and R. F. Schwan. 2011. Comparative study of the biochemical changes and volatile compound formations during the production of novel whey-based kefir beverages and traditional milk kefir. Food Chem. 126:249253. https://doi.org/10.1016/j.foodchem.2010.11.012.

Ministério da Agricultura e do Abastecimento, Brazil. 2005. Regulamento Técnico de Identidade e Qualidade de Bebidas Lácteas. Departamento de Inspeção de Produtos de Origem Animal. Instrução Normativa n.16. Secretaria de Defesa Agropecuária, Brasilia, Brazil.

Mishra, S., and H. N. Mishra. 2013. Effect of symbiotic interaction of fructooligosaccharide and probiotics on the acidification profile, textural and rheological characteristics of fermented soy milk. Food Bioprocess Technol. 6:3166-3176. https://doi.org/10.1007/ s11947-012-1021-4.

Mousavi, M., A. Heshmati, A. D. Garmakhany, A. Vahidinia, and M. Taheri. 2019. Optimization of the viability of Lactobacillus acidophilus and physicochemical, textural and sensorial characteristics of flaxseed-enriched stirred probiotic yogurt by using response surface methodology. LWT Food Sci. Technol. 102:80-88.

Oliveira, R. P. S., B. R. Torres, P. Perego, M. N. Oliveira, and A. Converti. 2012. Co-metabolic models of Streptococcus thermophilus in co-culture with Lactobacillus bulgaricus or Lactobacillus acidophilus. Biochem. Eng. J. 62:62-69. https://doi.org/10.1016/j.bej.2012 .01 .004 .

Parker, E. A., T. Roy, C. R. D'adamo, and L. S. Wieland. 2018. Probiotics and gastrointestinal conditions: An overview of evidence from the Cochrane Collaboration. Nutrition 45:125-134. https:// doi.org/10.1016/j.nut.2017.06.024.

Ranadheera, C. S., C. A. Evans, M. C. Adams, and S. K. Baines. 2012. In vitro analysis of gastrointestinal tolerance and intestinal cell ad- hesion of probiotics in goat's milk ice cream and yogurt. Food Res. Int. 49:619-625. https://doi.org/10.1016/j.foodres.2012.09.007.

Saccaro, D. M., C. Y. Hirota, A. Y. Tamime, and M. N. Oliveira. 2011. Evaluation of different selective media for enumeration of probiotic micro-organisms in combination with yogurt starter cultures in fermented milk. Afr. J. Microbiol. Res. 5:3901-3906. https://doi .org/10.5897/AJMR11.598.

Sfakianakis, P., and C. Tzia. 2014. Conventional and innovative processing of milk for yogurt manufacture; Development of texture and flavor: A review. Foods 3:176-193. https://doi.org/10.3390/ foods 3010176

Silva, T. M. S. (2015). Comportamento do ácido elágico em bebidas lácteas simbióticas suplementadas com L-triptofano e polpa de frutas vermelhas durante armazenamento refrigerado [Behaviour of ellagic acid in synbiotic lactic beverages supplemented with Ltryptophan and red fruit pulp during cold storage]. MD Thesis, Faculty of Pharmaceutical Sciences, University of São Paulo, São Paulo, Brazil. Accessed Apr. 12, 2020. http://www.teses.usp.br/ teses/disponiveis/9/9133/tde-30032016-144021/en.php.

Tavakoli, M., M. B. Habibi Najafi, and M. Mohebbi. 2019. Effect pf the milk fat content and starter culture selection on proteolysis and antioxidant activity of probiotic yogurt. Heliyon 5:e-01204. https://doi.org/10.1016/j.heliyon.2019.e01204.

Uriot, O., S. Denis, M. Junjua, Y. Roussel, A. Dary-Mourot, and S. Blanquet-Diot. 2017. Streptococcus thermophilus: From yogurt starter to a new promising probiotic candidate? J. Funct. Foods 37:74-89. https://doi.org/10.1016/j.jff.2017.07.038.

Verruck, S., E. S. Prudêncio, R. W. Vieira, E. R. Amante, and R. D. M. C. Amboni. 2015. The buffalo Minas Frescal cheese as a protective matrix of Bifidobacterium BB-12 under in vitro simulated gastrointestinal conditions. LWT Food Sci. Technol. 63:1179-1183. https://doi.org/10.1016/j.lwt.2015.04.014.

Yadav, H., S. Jain, and P. Sinha. 2007. Production of free fatty acids and conjugated linoleic acid in probiotic dahi containing Lactobacillus acidophilus and Lactobacillus casei during fermentation and storage. Int. Dairy J. 17:1006-1010. https://doi.org/10.1016/ j.idairyj.2006.12.003.

Zhou, L., Q. Tang, M. W. Iqbal, Z. Xia, F. Huang, L. Li, M. Liang, B. Lin, G. Qin, and C. Zou. 2018. A comparison of milk protein, fat, lactose, total solids and amino acid profiles of three different buffalo breeds in Guangxi, China. Ital. J. Anim. Sci. 17:873-878. https://doi.org/10.1080/1828051X.2018.1443288.

Ziar, H., P. Gérard, and A. Riazi. 2014. Effect of prebiotic carbohydrates on growth, bile survival and cholesterol uptake abilities of dairy-related bacteria. J. Sci. Food Agric. 94:1184-1190. https:// doi.org/10.1002/jsfa.6395. 